\title{
EKSTRAKSI MULTI TAHAP KURKUMIN DARI KUNYIT (Curcuma domestica Valet) MENGGUNAKAN PELARUT ETANOL
}

\author{
Rajian Sobri Rezki, Dwimas Anggoro, Siswarni MZ \\ Departemen Teknik Kimia, FakultasTeknik,Universitas Sumatera Utara, \\ Jl. Almamater Kampus USU Medan 20155, Indonesia \\ Email : rajian_sobri@hotmail.com
}

\begin{abstract}
Abstrak
Kurkumin adalah zat warna berupa kristal kuning oranye yang terdapat pada kunyit, yang sering digunakan sebagai pewarna. Metode yang biasa digunakan dalam esktraksi kurkumin dari kunyit adalah ekstraksi satu tahap. Penelitian ini mempelajari ekstraksi multi tahap kurkumin dari kunyit. Tujuan dari penelitian ini adalah mengetahui kondisi terbaik dalam ekstraksi multi tahap kurkumin dari kunyit (Curcuma domestica Valet), sehingga dapat digunakan untuk meningkatkan efisiensi prosesnya. Percobaan ini menggunakan pelarut etanol, dan yang diamati adalah pengaruh dari berbagai variabel proses yaitu waktu ekstraksi, konsentrasi pelarut, dan jumlah tahap ekstraksi. Waktu ekstraksi yang digunakan adalah 60 menit, 120 menit, dan 180 menit. Variasi konsentrasi etanol yang digunakan yaitu 50\%, 70\%, dan 96\%. Tahap ekstraksi yang digunakan adalah ekstraksi dua tahap dan ekstraksi tiga tahap. Ekstrak kurkumin yang diperoleh dianalisa dengan analisa kualitatif dan analisa kuantitatif. Kondisi terbaik dalam ekstraksi multi tahap kurkumin dari kunyit dipilih berdasarkan nilai rendemen dan kadar kurkumin yang diperoleh. Rendemen maksimum yang diperoleh pada percobaan ini adalah 12\% dengan kondisi waktu 180 menit, konsentrasi etanol $96 \%$ dan jumlah tahap ekstraksi 2 tahap. Adapun kadar kurkumin tertinggi yang didapat adalah $16 \%$ dengan waktu 180 menit, konsentrasi etanol 96\% dan jumlah tahap ekstraksi 3 tahap. Kadar di sini maksudnya adalah besar bagian kurkumin terhadap rendemen. Hasil yang diperoleh pada penelitian ini menunjukkan bahwa peningkatan waktu ekstraksi, konsentrasi pelarut, dan jumlah tahap ekstraksi meningkatkan perolehan rendemen ekstrak dan kadar kurkumin yang terekstraksi dari kunyit.
\end{abstract}

Kata kunci: kurkumin, ekstraksi, multi tahap, rendemen, kadar

\begin{abstract}
Curcumin is a pigment in Curcuma domestica Valet, which has an orange-yellow crystal appearance, and commonly being used as a colouring agent. Extraction method which is used in extracting curcumin from Curcuma domestica Valet is one stage extraction. This research studied a multi stages extraction of curcumin from Curcuma domestica Valet. The purposes of this research is to find the best condition in extracting curcumin using multi stages extraction method, to increase the efficiency rate in curcumin extraction. This research used ethanol as a solvent, and effect from variables such as extraction time, solvent concentration, and number of extraction stages are observed. Extraction times are 60 minutes, 120 minutes, and 180 minutes. Variations of ethanol concentration are 50\%, $70 \%$, and $96 \%$. Stage numbers of extraction are two stages extraction and three stages extraction. Extracts of curcumin are examined with qualitative analysis and quantitative analysis. The best condition of multi stages curcumin extraction is determined based on yield and content of curcumin. The maximum yield obtained in this study was $12 \%$ with conditions 180 minutes extraction time, $96 \%$ ethanol concentration, and two stages extraction. The highest content of curcumin obtained is $16 \%$ with conditions 180 minutes extraction time, 96\% ethanol concentration, and three stages extraction. Content means a fraction of yield. These results show that increase in extraction time, solvent concentration, and stage numbers of extraction will increase the yield and content of curcumin extracted from Curcuma domestica Valet.
\end{abstract}

Keywords: curcumin, extraction, multi stages, yield, content

\section{Pendahuluan}

Indonesia adalah salah satu bangsa agraris yang sebagian besar warganya bergelut di sektor pertanian, dengan berbagai produk yang bervariasi [12]. Kunyit, yang merupakan salah satu komoditas pertanian di Indonesia, memiliki kandungan kurkumin yang cukup tinggi [7].

Kurkumin dapat digunakan sebagai pewarna makanan, di dalam produk olahan sehari-hari, juga memiliki banyak potensi di bidang pengobatan $[2,3,9]$.

Minat akan penggunaan kurkumin ditandai dengan adanya berbagai penelitian mengenai ekstraksi satu tahap kurkumin dari kunyit yang telah dilakukan sebelumnya, misalnya Harjanti yang mendapatkan suhu ekstraksi terbaik $70^{\circ} \mathrm{C}$ [8]. Juga Wahyuni yang mendapatkan volume 
pelarut terbaik $300 \mathrm{ml}$ [12], dan Popuri yang mendapati etanol sebagai pelarut terbaik dibandingkan berbagai pelarut lainnya [4].

Namun semua penelitian itu menggunakan metode ekstraksi satu tahap, sedangkan Menurut Muhiedin, metode ekstraksi multi tahap dengan volume pelarut lebih sedikit akan lebih efektif dibanding ekstraksi satu tahap dengan semua pelarut sekaligus [6], dan penelitian mengenai ekstraksi multi tahap kurkumin dari kunyit belum banyak dilakukan.

Atas dasar pemikiran tersebut, maka penulis ingin melakukan penelitian ekstraksi multi tahap kurkumin dari kunyit.

\section{Teori}

Kurkumin, atau disebut juga dengan [1,7bis(4-hydroxy-3-methoxyfenil)-1,6-heptadiene-

3,5-dione], adalah sebuah senyawa pewarna alami kuning-oranye [13], yang terdapat pada kunyit [8]. Kunyit (Curcuma Domestica Valet) termasuk dalam klasifikasi sebagai berikut :

$\begin{array}{ll}\text { Kingdom } & \text { : Plantae } \\ \text { Divisi } & \text { : Spermatophyta } \\ \text { Sub Divisi } & \text { : Angiospermae } \\ \text { Kelas } & \text { : Monocotyledonae } \\ \text { Ordo } & \text { : Zingiberales } \\ \text { Famili } & \text { : Zingiberaceae } \\ \text { Genus } & \text { : Curcuma } \\ \text { Spesies } & \text { : Curcuma Domestica Valet } \\ \end{array}$

Struktur kimia kurkumin dapat dilihat pada Gambar 1 :<smiles>COc1cc(/C=C/C(=O)CC(=O)/C=C/c2ccc(O)c(OC)c2)ccc1O</smiles>

\section{Gambar 1. Struktur Kimia Kurkumin [4]}

Kurkumin dapat dipisahkan melalui proses ekstraksi [1]. Definisi umum ekstraksi yaitu proses pemisahan dan isolasi zat dari suatu zat dengan penambahan pelarut tertentu untuk mengeluarkan komponen campuran dari zat padat atau zat cair. Dalam hal ini fraksi padat yang diinginkan bersifat larut dalam pelarut (solvent), sedangkan fraksi padat lainnya tidak dapat larut [12].

Komponen yang dipindahkan dari zat padat ke dalam pelarut disebut "solute" sedangkan padatan yang tidak terlarut dalam pelarut disebut "inert" [11]. Proses tersebut akan menjadi sempurna jika solut dipisahkan dari pelarutnya, misalnya dengan cara distilasi/penguapan [12].

Ekstraksi dapat dilakukan dengan metode satu tahap maupun metode multi tahap. Penelitian ini menggunakan ekstraksi multi tahap dengan aliran silang (cross-current), yang skemanya dapat dilihat pada Gambar 2. Pada metode ini terjadi kontak antara padatan dan pelarut yang dilakukan dalam beberapa tahap dimana rafinat yang diperoleh dari tahap yang satu dikontakkan dengan pelarut baru pada tahap berikutnya. Faktor-faktor yang mempengaruhi unjuk kerja ekstraksi antara lain adalah ukuran partikel, temperatur ekstraksi, jumlah pelarut, dan waktu ekstraksi [11].

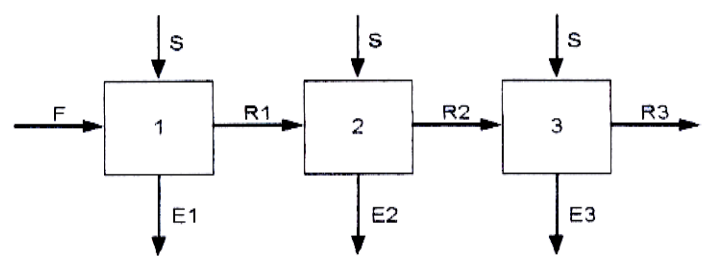

Gambar 2. Skema Ekstraksi Multi Tahap dengan Aliran Silang [11]

\section{Metodologi Penelitian \\ Bahan dan Alat}

Adapun bahan yang digunakan dalam penelitian ini adalah kunyit, Etanol 96\% $\left(\mathrm{C}_{2} \mathrm{H}_{5} \mathrm{OH}\right)$, dan Aquadest $\left(\mathrm{H}_{2} \mathrm{O}\right)$. Untuk analisa digunakan kurkumin standar dari perusahaan Sigmaaldrich.

Alat yang digunakan dalam penelitian ini adalah penangas air, labu leher tiga, hot plate, termometer, refluks kondensor, statif dan klem, selang, corong gelas, erlenmyer, gelas ukur, kertas saring, dan oven.

\section{Persiapan Bahan Baku Kunyit}

Kunyit segar dipilih dan dicuci, lalu dikupas kulitnya, dipotong kecil kecil, dikeringkan dan diblender hingga halus.

\section{Ekstraksi Kurkumin}

Sebanyak 20 gram kunyit dimasukkan kedalam labu leher tiga, lalu diekstraksi dengan etanol 50\%, 70\% dan 96\% dengan perbandingan bahan baku : pelarut (1:4) b/v, selama waktu 60 , 120 dan 180 menit dengan jumlah tahap ekstraksi dua dan tiga tahap. Rafinat yang didapat kemudian didistilasi dan dianalisa.

\section{Distilasi}

Pertama-tama filtrat dari ekstraksi pertama dan lanjutan dimasukkan ke dalam labu distilasi untuk memisahkan kurkumin dari pelarut. Selanjutnya pemanas dihidupkan dan setelah proses distilasi pada suhu $80^{\circ} \mathrm{C}$ diperoleh hasil berupa pelarut dan residu. Setelah itu residu dikeringkan di dalam oven pada suhu $100^{\circ} \mathrm{C}$ untuk menghilangkan sisa etanol dan air yang masih terdapat dalam kurkumin. Lalu dilakukan penimbangan sampai diperoleh berat konstan. 


\section{Analisa}

Analisa yang dilakukan meliputi analisa kualitatif dan analisa kuantitatif. Analisa kualitatif meliputi penampilan, warna, bau, serta kelarutan dalam air dan alkohol. Analisa kuantitatif meliputi perhitungan rendemen dan kadar kurkumin. Rendemen dihitung dengan persamaan 1 [6]:

Rendemen $=\left(\mathrm{M}_{2} / \mathrm{M}_{1}\right) \times 100 \%$

Dimana $\mathrm{M}_{1}$ adalah berat bahan baku awal dan $\mathrm{M}_{2}$ adalah berat ekstrak yang didapat. Analisa kuantitaif dilakukan menggunakan spektrofotometer $u v$-visible. Ekstrak yang telah diencerkan dimasukkan ke spektrofotometer, lalu skala absorbansinya dibaca pada panjang gelombang $425 \mathrm{~nm}$, dan dicatat. Konsentrasi kurkumin dihitung dengan grafik kurkumin standar absorbansi vs konsentrasi.

\section{Hasil dan Pembahasan \\ Analisa Kualitatif}

Berdasarkan pengamatan, produk memiliki penampilan berupa pasta berwarna cokelat kemerahan dengan bau yang khas, sukar larut dalam air tapi mudah larut dalam alkohol.

\section{Analisa Rendemen Ekstrak}

\section{Pengaruh Waktu Ekstraksi terhadap} Rendemen Ekstrak

Pada Gambar 3 dapat dilihat bahwa rendemen ekstrak yang dihasilkan untuk berbagai macam konsentrasi pelarut dan tahap jumlah ekstraksi cenderung meningkat dengan peningkatan waktu, dimana dapat dilihat pada waktu ekstraksi selama 180 menit menghasilkan rendemen ekstrak yang lebih banyak (3,5-12\%) dibandingkan waktu 60 menit $(2,8-8,25 \%)$ dan 120 menit $(3,5-8,7 \%)$.

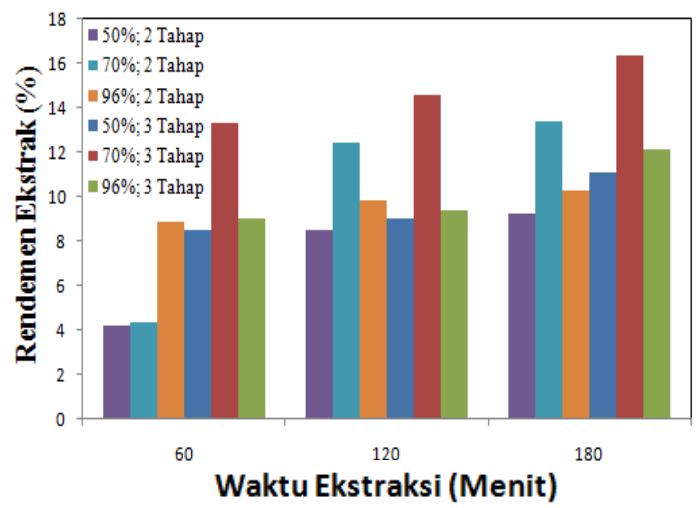

Gambar 3. Pengaruh Waktu Ekstraksi terhadap Rendemen Ekstrak
Semakin lama waktu ekstraksi, maka \% hasil yang diperoleh semakin besar [12]. Hal ini disebabkan karena waktu kontak antara kurkumin dengan pelarutnya semakin lama. Kondisi ini akan terus berlanjut hingga waktu kontak yang diperlukan pelarut dengan bahan kunyit sudah cukup dan mencapai kondisi kesetimbangan [8].

\section{Pengaruh Konsentrasi Pelarut terhadap Rendemen Ekstrak}

Pada Gambar 4 dapat dilihat bahwa rendemen ekstrak yang dihasilkan cenderung meningkat dengan peningkatan konsentrasi pelarut, dimana dapat dilihat pada konsentrasi pelarut $96 \%$ menghasilkan rendemen ekstrak yang lebih banyak (6,7-12\%) dibandingkan konsentrasi pelarut $50 \%(2,8-8,8 \%)$ dan $70 \%$ $(3,5-7,4 \%)$.



Gambar 4. Pengaruh Konsentrasi Pelarut terhadap Rendemen Ekstrak

Menurut Popuri, konstituen aktif dalam kunyit, yakni kurkuminoid (termasuk di dalamnya kurkumin) sedikit larut dalam pelarut hidrokarbon namun mudah larut dalam pelarut alkohol seperti etanol dan metanol. Alkohol dan aseton adalah ekstraktan yang baik dan rendemennya pun tinggi. Semakin tinggi konsentrasi pelarut, semakin tinggilah kemurnian etanol dalam pelarut, sehingga semakin banyak kurkumin yang terekstrak ke dalam etanol. Rendemen pun semakin besar [4].

\section{Pengaruh Jumlah Tahap Ekstraksi terhadap Rendemen Ekstrak}

Pada Gambar 5 dapat dilihat bahwa rendemen ekstrak yang dihasilkan cenderung menurun dengan peningkatan jumlah tahap ekstraksi, dimana pada tahap ekstraksi sebanyak 2 tahap menghasilkan rendemen ekstrak yang lebih banyak (3,5-12\%) dibandingkan ekstraksi 3 tahap $(2,8-10,05 \%)$. 
Ekstraksi beberapa kali dengan pelarut yang lebih sedikit akan lebih efektif dibanding ekstraksi satu kali dengan semua pelarut sekaligus [6]. Hal ini disebabkan karena pada setiap tahap akan terjadi kontak dengan pelarut baru yang memberikan driving force berupa perbedaan konsentrasi dan kelarutan dalam setiap tahapnya sehingga akan selalu terjadi perpindahan solut dari padatan ke pelarut, namun pada satu titik perolehan ekstrak akan menurun. Ini disebabkan pada ekstraksi multitahap crosscurrent padatan yang digunakan pada setiap tahap adalah padatan yang sama sehingga ekstrak semakin lama akan semakin jenuh, hingga perolehan ekstrak tidak lagi meningkat dan akan menurun [11].

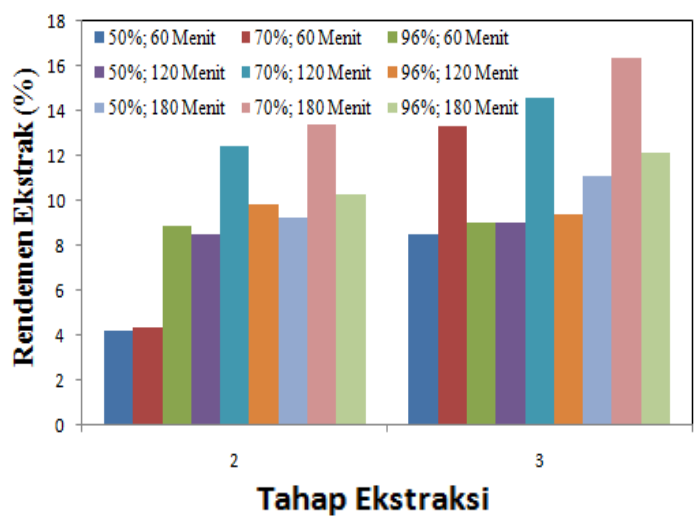

Gambar 5. Pengaruh Jumlah Tahap Ekstraksi terhadap Rendemen Ekstrak

\section{Pembuatan Kurva Standar Kurkumin}

Pada Gambar 6, ditunjukkan bahwa dari grafik kurva standar kurkumin absorbansi vs konsentrasi, diperoleh persamaan $\mathrm{y}=0,363 \mathrm{x}+$ 0,021 dengan $R^{2}=0.990$. Dengan menggunakan persamaan tersebut maka konsentrasi kurkumin untuk setiap percobaan dapat dihitung.

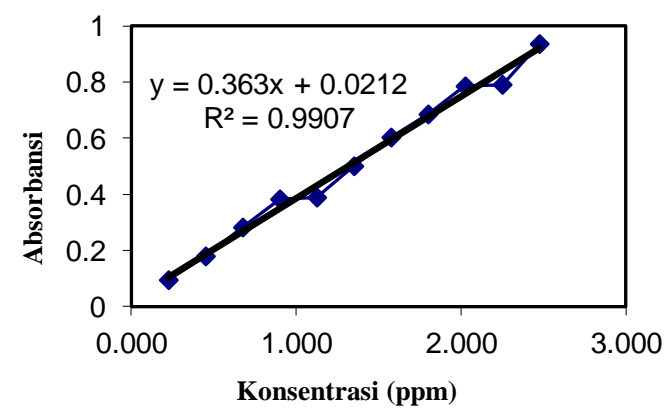

Gambar 6. Kurva Standar Kurkumin

Analisa Kadar Kurkumin

Pengaruh Waktu Ekstraksi terhadap Kadar Kurkumin
Pada Gambar 7 dapat dilihat bahwa kadar kurkumin yang dihasilkan cenderung meningkat dengan peningkatan waktu, dimana pada waktu ekstraksi selama 180 menit (0,0278-16\%) menghasilkan kadar kurkumin yang lebih tinggi dibandingkan waktu 60 menit $(0,0891-10,77 \%)$ dan 120 menit $(0,0831-13,47 \%)$.

Semakin lama waktu ekstraksi, maka \% hasil yang diperoleh semakin besar [12]. Hal ini disebabkan karena waktu kontak antara kurkumin dengan pelarutnya semakin lama. Kondisi ini akan terus berlanjut hingga waktu kontak yang diperlukan pelarut dengan bahan kunyit sudah cukup dan mencapai kondisi kesetimbangan [8].

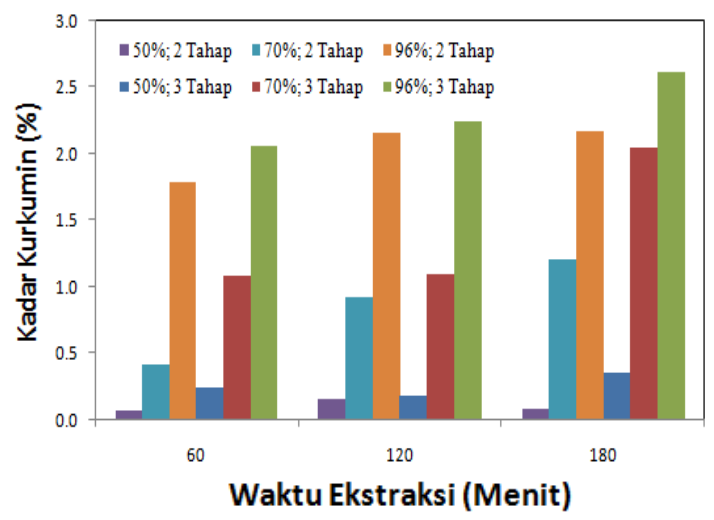

Gambar 7. Pengaruh Waktu Ekstraksi terhadap Kadar Kurkumin

Pengaruh Konsentrasi Pelarut terhadap Kadar Kurkumin

Pada Gambar 8 dapat dilihat bahwa kadar kurkumin yang dihasilkan cenderung meningkat dengan peningkatan konsentrasi pelarut, dimana pada konsentrasi pelarut $96 \%$ menghasilkan rendemen ekstrak yang lebih banyak $(8,506-$ $16,001 \%$ ) dibandingkan konsentrasi pelarut $50 \%$ $(0,028-0,593 \%)$ dan $70 \%(0,148-15,545 \%)$.

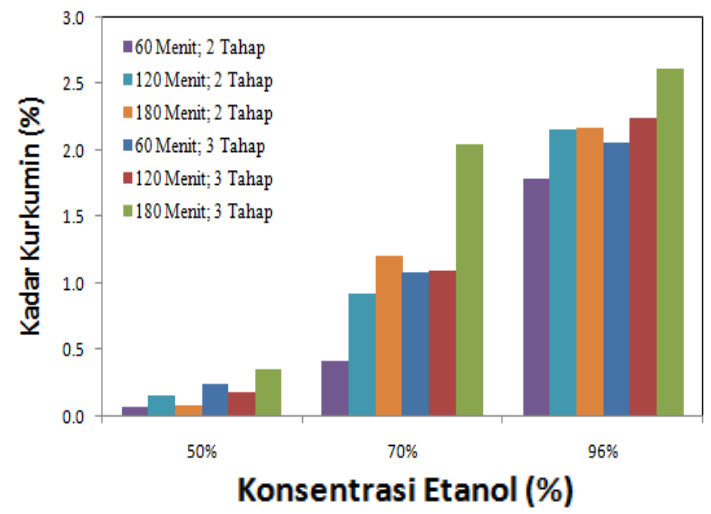

Gambar 8. Pengaruh Konsentrasi Pelarut terhadap Kadar Kurkumin 
Menurut Popuri, kurkumin merupakan senyawa non-polar liposoluble yang tidak larut dalam air, tetapi cukup larut dalam pelarut organik, dan larut dengan baik dalam pelarut alkohol yang bersifat semi-polar (etanol dan metanol). Jadi semakin tinggi konsentrasi etanol, akan semakin banyaklah kandungan etanol, sehingga semakin banyak kurkumin yang larut ke dalam etanol, dan semakin banyak kurkumin yang teresktrak [4].

\section{Pengaruh Jumlah Tahap Ekstraksi terhadap Kadar Kurkumin}

Pada Gambar 9 dapat dilihat bahwa kadar kurkumin yang dihasilkan cenderung meningkat dengan peningkatan jumlah tahap ekstraksi, dimana pada ekstraksi sebanyak 3 tahap menghasilkan kadar kurkumin yang lebih banyak $(0,028-16,001 \%)$ dibandingkan ekstraksi 2 tahap $(0,083-15,15 \%)$, tetapi perbedaannya tipis.

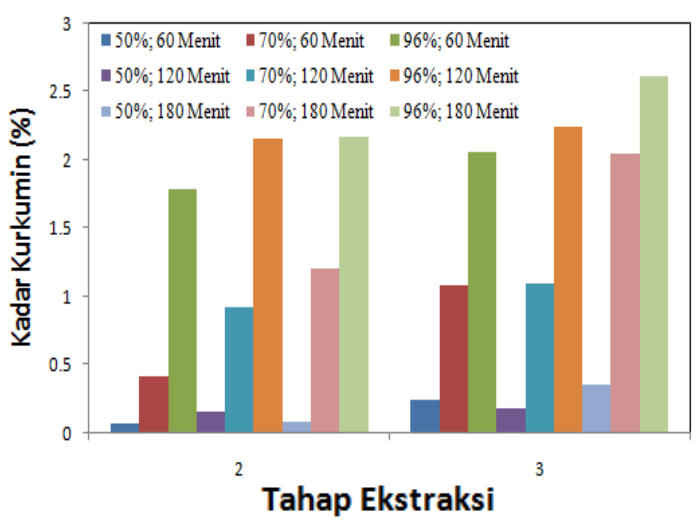

\section{Gambar 9. Pengaruh Jumlah Tahap Ekstraksi terhadap Kadar Kurkumin}

Ekstraksi beberapa kali dengan pelarut yang lebih sedikit akan lebih efektif dibanding ekstraksi satu kali dengan semua pelarut sekaligus [6]. Hal ini disebabkan karena pada setiap tahap akan terjadi kontak dengan pelarut baru yang memberikan driving force berupa perbedaan konsentrasi dan kelarutan dalam setiap tahapnya sehingga akan selalu terjadi perpindahan solut dari padatan ke pelarut [11], juga karena kandungan yang tertinggal dalam ampas sisa ekstraksi sebelumnya dapat diekstrak pada proses ekstraksi selanjutnya [6], sehingga bertambahnya jumlah tahap ekstraksi akan meningkatkan jumlah ekstrak yang diperoleh.

\section{Perbandingan Perolehan Kurkumin}

Dari penelitian sebelumnya yang melakukan ekstraksi satu tahap kurkumin dari kunyit, diantaranya adalah Dong Liu (2008) yang mendapat kadar kurkumin 6,8\% [5], dan Himesh (2011) yang mendapat kadar kurkumin 10,23\% [10].
Sementara itu, penelitian ini mendapatkan kadar $15,15 \%$ pada ekstraksi dua tahap dan $16,001 \%$ pada ekstraksi tiga tahap. Terlihat bahwa dibandingkan dengan ekstraksi satu tahap, peningkatan cukup besar diberikan oleh ekstraksi dua tahap $(4,9-8,35 \%)$ dan ekstraksi tiga tahap $(5,77-9,201 \%)$.

Perlu diperhatikan bahwa kadar kurkumin di sini maksudnya adalah besar kadar terhadap rendemen, dan rendemen adalah berat produk yang didapat dari setiap run dibandingkan terhadap berat bahan baku kunyit.

Dari hasil ini terlihat bahwa ekstraksi multi tahap memberikan peningkatan perolehan yang besar dibandingkan dengan ekstraksi satu tahap. Karena selisih perolehan kadar kurkumin dari ekstraksi tiga tahap dan ekstraksi dua tahap tidak terlalu besar $(0,851 \%)$, ekstraksi dua tahap lebih disarankan untuk digunakan. Dan, dari segi ekonomi, diperlukan perhitungan yang lebih dalam dan terperinci jika ingin menggunakan metode ekstraksi dua tahap untuk mengekstraksi kurkumin dari kunyit dalam skala pabrik.

\section{Kesimpulan}

Dari penelitian yang telah dilakukan dapat ditarik kesimpulan bahwa :

1. Rendemen ekstrak tertinggi yang diperoleh yaitu $12 \%$ dengan waktu 180 menit, konsentrasi pelarut $96 \%$ dan 2 tahap ekstraksi. Sedangkan kadar kurkumin tertinggi yang diperoleh yaitu $16 \%$ dengan waktu 180 menit, konsentrasi pelarut $96 \%$ dan 3 tahap ekstraksi.

2. Perolehan rendemen ekstrak dan kadar kurkumin semakin meningkat dengan lamanya waktu ekstraksi, besarnya konsentrasi pelarut, dan jumlah tahap ekstraksi.

3. Ekstraksi multi tahap memberikan peningkatan perolehan yang cukup besar dibandingkan dengan ekstraksi satu tahap.

4. Dalam penelitian ini, waktu ekstraksi terbaik adalah 180 menit.

5. Dalam penelitian ini, konsentrasi etanol terbaik adalah $96 \%$.

6. Dari penelitian ini, ekstraksi dua tahap lebih disarankan untuk digunakan dalam mengekstrak kurkumin dari kunyit.

\section{Daftar Pustaka}

[1] Anamika Bagchi, Extraction of Curcumin, IOSR Journal of Environmental Science, Toxicology and Food Technology (IOSRJESTFT), 1 (3), page 4, 2012.

[2] Andrew M. Anderson, Matthew S. Mitchell, dan Ram S. Mohan., Isolation of Curcumin from Turmeric, Journal of Chemical Education, Department of Chemistry, 
Illinois University, Bloomington, 77 (3), page 359, 2000.

[3] Arunava Gantait, Topu Barman, dan Pulok K. Mukherjee., Validated Method for Estimation of Curcumin in Turmeric Powder, Indian Journal of Traditional Knowledge, 10 (2), page. 247, 2011.

[4] Ashok Kumar Popuri, Bangaraiah Pagala, Extraction of Curcumin from Turmeric Roots, International Journal of Innovative Research \& Studies, 2 (5), hal. 293, 2013.

[5] Dong Liu, Joshua Schwimer, Zhijun Liu, Eugene A. Woltering, dan Frank L. Greenway, Antiangiogenic Effect of Curcumin in Pure Versus in Extract Forms, Pharmaceutical Biology, 46 (10-11), page 677, 2008.

[6] Fuad Muhiedin, Efisiensi Proses Ekstraksi Oleoresin Lada Hitam dengan Metode Ekstraksi Multi Tahap, Skripsi, Program Sarjana, Fakultas Teknologi Pertanian Universitas Brawijaya, Malang, hal. 2-3, 29, 2008.

[7] Mahreni dan Sri Mulyani, Pemodelan Sistem Ekstraksi Padat Cair Tipe Unggun Tetap, Prosiding Seminar Nasional Fundamental dan Aplikasi Teknik Kimia, Surabaya, hal. FP.04-2, 2002.

[8] Ratna Sri Harjanti, Pemungutan Kurkumin dari Kunyit (Curcuma domestica val.) dan Pemakaiannya Sebagai Indikator Analisis Volumetri, Jurnal Rekayasa Proses, 2 (2), hal. 51-53, 2008.

[9] S. J. Kulkarni, K. N. Maske, M. P. Budre, R. P. Mahajan, Extraction and Purification of curcuminoids from Turmeric (curcuma longa L.). International Journal of Pharmacology and Pharmaceutical Technology, 1 (2), page. 81, 2012.

[10] Soni Himesh, Patel Sita Sharan, Mishra K, Nayak Govind, Singhai Ak. Lakshmi, Qualitative and Quantitative Profile of Curcumin from Ethanolic Extract of curcuma longa, International Research Journal of Pharmacy, 2(4), page. 183, 2011.

[11] Susiana Prasetyo S., A. Prima K, Kurva Kesetimbangan Minyak Biji Teh-Normal Heksana dan Aplikasinya pada Ekstraksi Padat - Cair Multitahap, Skripsi, Universitas Katolik Parahyangan, Bandung, hal. 20-23, 2009.

[12] Wahyuni, A. Hardjono, Paskalina Hariyantiwasi Yamrewav, Ekstraksi Kurkumin dari Kunyit, Prosiding Seminar Nasional Rekayasa Kimia dan Proses, Semarang, hal. F-17-1 dan F-17-5, 2004.

[13] Zaibunnisa, A.H.,Norashikin, S., Mamot, S. dan Osman, H., Stability of Curcumin in Turmeric Oleoresin $-\beta-$ Cyclodextrin
Inclusion Complex During Storage, The Malaysian Journal of Analytical Science, 13 (2), page. 165, 2009. 